\title{
Critical Issues of Sustainability Associated with Quarry Activities
}

\author{
Nwachukwu MA*, Ojeaga K and Gilbert Chinelo \\ Department of Environmental Technology, Federal University of Technology Owerri, Nigeria \\ *Corresponding author: Nwachukwu MA, Department of Environmental Technology, Federal University of Technology Owerri, Nigeria
}

Submission: 眥 February 02, 2018; Published: 眥 February 23, 2018

\begin{abstract}
The concern that quarry activities threaten the sustainability of total environment in many developing countries is on the increase. To address this issue with affordable solution, Iyuku community of Auchi, Nigeria, has been investigated. Field study found micro to mega cracks on the wall of structures, often causing collapse. Abandoned pits turn pond, causing groundwater pollution, and breed disease vectors. Noise from rock blasting and other quarry operations are responsible for loss of biodiversity particularly birds. Soil samples were collected at depths 0-15 and $15-30 \mathrm{~cm}$ from the three quarry sites and from a control, $1 \mathrm{~km}$ off the quarry sites, against the direction of drainage. Water sample was also collected from an abandoned quarry pit turned pond. These samples were analyzed for heavy metals and physico-chemical properties. Atomic Absorption Spectrophometer (VGP 210 Bulk scientific) was used for heavy metal analysis and Flame photometer (M410 SHERWOOD) was used to measure sodium and potassium. All physico-chemical properties and heavy metals tested of the soil showed positive anomaly with the control (background values), confirming total degradation and unsustainable mining practice. Future study will focus on the chemistry and level of dust in ambient air, and how to minimize blasting vibrations and noise level in the area.
\end{abstract}

Keywords: Environmental degradation; Heavy metals; Physico-chemical parameters; Quarry; Sustainability

\section{Introduction}

\section{The study area}

This Study was carried out in Iyuku community in Auchi, Edo State Nigeria. Its geographical coordinates are $7^{\circ} 4^{\prime} 0^{\prime \prime}$ North, $6^{\circ}$ $16^{\prime} 0^{\prime \prime}$ East The active quarry companies in the area were Julius Dinga Quarry Limited, Dele Investment Company and Consolidated Contractors Company (CCC) Quarry limited. Within the mining area is an abandoned quarry pit turned pond whose water source may be attributed to rainfall drainage and seepage of water from fractures. Figure 1 is map of Iyuku projected from map of Edo state and identified in an index map of Nigeria.

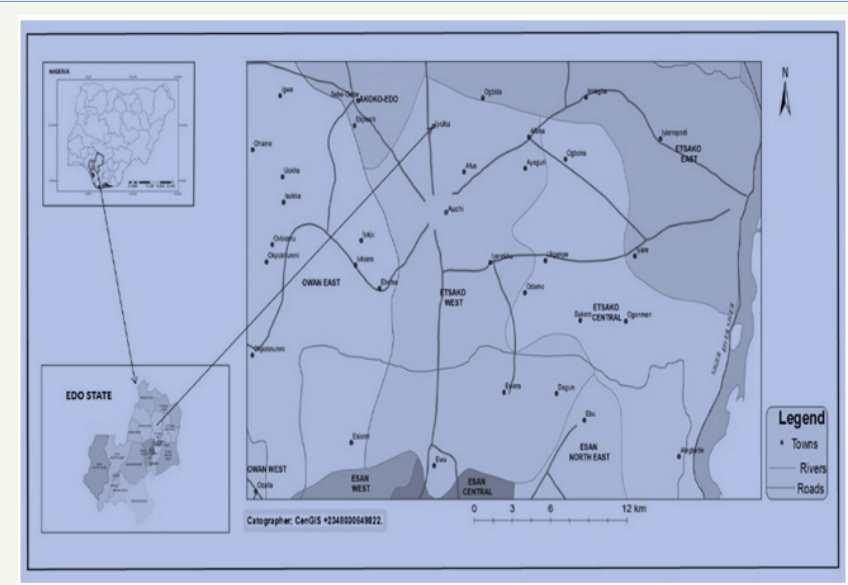

Figure 1: Map of Iyuku projected from Edo state, and Edo state projected from Index map of Nigeria.

\section{Benefits and problems of hard rock quarry}

Rock quarry has been in Iyuku for about two decades. There are seven quarries in Iyuku community, with only three currently active. These quarries produce aggregates for road bases and for concrete. Rock quarry is the major business in Iyuku because its operations and activities has brought economic development, creates employment opportunities to people and serves as source of revenue generation for the Local Government council. Internally generated revenue from quarries has been used for the provision of basic infrastructural needs of the community which includes construction of roads, school buildings, and rural electrification projects. Quarry activities in Iyuku have left behind devastated landscape, exposed fertile lands to erosion, and abandoned quarry pit turned pond. Though the pond could be used for irrigation, livestock feeding and in very rare occasion for domestic uses, pollutants could migrate from the pond to impact groundwater. Quarry operations have the potential of releasing dust loaded with heavy metals into the environment.

\section{Brief geology}

Sedimentary and Crystalline Basement Complex rocks are in occurrence in Iyuku. This is associated with a cretaceous sandstone deposits belonging to the Lokoja-Basange Formation. The LokojaBasange Formation forms the Northern limit of Southwest Nigeria sedimentary basin underlying a quarter of Iyuku while the rest is underlain by extensive igneous rocks (Granite and Pegmatite) whose surface expression is circular to elliptical [1]. 


\section{Literature Review}

Quarrying is a form of land use method concerned with the extraction of non-fuel and non-metal minerals from rock. Quarries produce aggregates used for building and other civil constructions. Keeperman [2] defined quarry as an act of exploring and exploiting rocks from the earth crust. A wide variety of products from quarries form primary raw materials in many industrial applications. Crushed rocks are used as aggregate in highways or concrete and in bitumen plants and rail track construction. Quarry operations are carried out by diverse surface methods such as hard rock blasting, sand and soil excavation, alluvial dredging and solution mining. Method used depends on the material target, nature of the target, depth below the surface, and location of the deposit. Each mining method has its own impact on the environment. Rock and mineral resources cannot be extracted from the earth without some environmental impacts.

Quarry operations can cause serious environmental degradation when proper siting, design, operation and monitoring are not provided [3]. Quarry activities such as exploration, blasting, transportation and disposal of waste rocks impacts environmental destroys vegetation, natural habitats and cause dust-air pollution. They also impact natural drainage systems, causing soil erosion and river siltation [4]. Quarry noise and vibration can lead to formation of micro cracks that could turn to mega cracks with time, causing failure of nearby structures [5]. According to Stehouwer et al. [6] quarry activities exert tremendous pressure on limited soil and water resources, thus increasing the rate of erosion processes and subsequent damage of existing arable lands. Lad \& Samant [7] observed that social challenges related to the increase in quarry activities includes, threats to health and safety, displacement of communities, damage of cultural sites. While the mining companies and the government benefits from quarrying activity, host communities suffer from the negative impacts. This has led to persistent conflicts between the quarry operators and the host communities [8]. Common conflicts revolve around selfdetermination and resource control, land use compensation, infrastructural development, pollution and land degradation and reclamation.

One of the biggest negative impacts of quarrying on the environment is the damage to biodiversity. Biodiversity conservation is important as all species are interlinked and our survival depends on the fine balance that exists within nature [9]. Quarry activity has the potential to destroying habitats and species Mabogunje [10]. Onyedika \& Nwosu [11], Oluyemi et al. [12] and Ashraf et al. [13] suggested that quarrying activities are well known for their deleterious effect on the environment due to the deposition of large volume of waste on the soil. Ezeaku [14] then observed that exposure of the soil to run-off and the release of harmful minerals and chemicals through quarry activities contaminate soil, water, plant and air quality. Quarry operation could modify the routing of recharge, causing degradation of water quality [15]. In temperate areas removing vegetation and soil reduces vapour transpiration and increases erosion. Idris et al. [16] stated that direct degradation can occur to ground water situation downhill from flow of water resulting from regular dewatering of the quarry pit.

Blasting may cause problems with groundwater quality. (Vincent et al. reported that shock waves from blasting operations loosened clay particles from solution cavities causing "muddying" of the ground water. However, Ukpong [17] investigated the impact of quarry blasting on ground-water quality and determined there was no relationship between blasting and quality of water in wells in the situation that they studied. The risk of ground water pollution may increase if the direction of groundwater flow is modified. New source areas of recharge may be introduced, and those sources may contain contaminated water. This situation can arise because of ground-water pumping [18]. Igwe et al. [18] also reported that rock blasting associated with quarry may close existing groundwater passages, or may open new passage, resulting in a change in direction of groundwater flow. Noise could adversely affect wildlife by interfering with communication and masking the sounds of predators and prey, and in the extreme, result in temporary or permanent hearing loss and migration [19].

Lad \& Samant [19] also raised concerns that are directly proportional to the impacts of dust on human health and the environment. Dust, if uncontrolled, may spread over the surroundings during dry weather, leach into the soil during storms, and create harmful conditions for the flora and fauna [15]. When dust cover leaf surfaces, vegetation can be damaged through the blocking of leaf stomata, thus inhibiting gas exchange and reducing photosynthesis. In some situations, dust on quarry floors and nearby areas can clog pores in the ground, thus altering recharge rates. In other situations, dust can enter conduits and smaller openings, and can be transported and deposited into caves [15]. Soil $\mathrm{pH}$ which determines the basic and acidic properties of soil plays a significant role in nutrients needed by plant for growth. If the $\mathrm{pH}$ values obtained for the various quarry sites shows low acidic $\mathrm{pH}$ from the discharge points and increased towards alkalinity distance away from discharge points, could be attributed to higher effect of mining effluent at the discharge points, which is not good enough for the soil. Low acidic soil $\mathrm{pH}$ has been shown to increase metal phyto availability [17,20]. According to Stehouwer et al. [6] and Okafor [21] quarrying activities exert tremendous pressure on environment, impacting soil and water resources, thus increasing the rate of erosion processes with subsequent damage of arable lands. Aremu et al. [22] has reported that mining activities have left behind devastated landscape, exposed fertile lands, artificial dams, paddocks and abandoned ponds. It has also endangered the life of both flora and fauna in Udege area. Nevertheless, with careful planning and management, it is possible to minimize the effect on biodiversity and in fact, quarries can also provide a good opportunity to create new habitats [23].

\section{Materials and Method}

\section{Primary data}

Primary data were obtained from preliminary field investigation by GPS mapping across the area to determine the 
direction of drainage. The elevations and coordinates of the study areas were measured using Garmin Etrex Global Positioning System (GPS) and recorded in a field note book. Field coodinates and elevation data collected were placed in decimal formats and digitized in a Surfer software a powerful contouring, gridding, and surface mapping package) to produce a contour and drainage maps respectively which interpolates irregularly spaced XYZ data into a regularly spaced grid. The shape of the surface which is the topography of the study area is shown by the contour lines. Vertical electrical sounding (VES) was conducted across the quarry areas to determine depth to water table and subsurface lithology. Soil samples were collected from three (3) locations to determine their physico-chemical properties and heavy metal concentration. The physico-chemical and heavy metal characteristics of water from the abandoned pit were also determined. Secondary data about Iyuku were obtained from different literatures and oral interview from residents and staff of Julius Dinga, Consolidated Contractors Company (CCC) Quarry limited, and Dele Investment Company.

\section{Field techniques}

Composite soil samples were taken from two depths; surface $(0-15 \mathrm{~cm})$ and subsurface $(15-30 \mathrm{~cm})$ at the established referenced points which were Pits 1, 2, 3 and from a Control point not under the influence of quarry activities, located about $1000 \mathrm{~m}$ away from the quarry points. The soil samples were obtained from different topographical locations using soil auger at intervals of $100 \mathrm{~m}$ from each quarry pit. The coordinates of the sampling stations were Georeferenced using a Magellan Spot Track Map Global Positioning System (GPS) at the prescribed transects and distance intervals. The samples were put in labeled brown polyethylene bags and transported to the Laboratory where they were analyzed.

The Physico-chemical parameters of soil samples were determined by known Laboratory standard procedures and heavy metal contents were determined using Atomic Absorption Spectrophometer (VGP210 Bulk scientific). Sodium and potassium were determined using a flame photometer (M410 SHERWOOD). The water sample collected from the pond were analyzed for its metal contents and physico-chemical parameters using Atomic Absorption Spectrophometer (VGP210 Buck scientific) and results compared with federal ministry of environment standards. Vertical electrical sounding was conducted within the quarry area for the measurement of the apparent resistivity of the earth material using Omega 500 resistivity meter. Vertical Electrical Sounding (VES) was conducted using the famous Schlumberger 4 electrode arrangement. Data collected was subjected to the advanced geosciences $1 \mathrm{~d}$ inversion processing software for proper visualization of the subsurface lithilogy

\section{Analytical techniques}

The under listed physico-chemical parameters were analyzed using standard methods
i. Exchangeable Acidity
ii. Sulphate Determination

iii. Total Phosphorus.

iv. Exchangeable sodium and potassium and

v. pH Determination

Nitric-perchloric Digestion was carried out on the soil samples followed by reagent blank prepared for $\mathrm{Fe}, \mathrm{Mn}, \mathrm{Cu}, \mathrm{Zn}, \mathrm{Pb}, \mathrm{Ca}$, and $\mathrm{Al}$, while concentrations were determined by Atomic absorption spectrophotometer (Buck scientific 210 VGP). Soil data collected were subjected to statistical analysis using One Way Analysis of Variance (ANOVA) and bar chart statistic. All determinations were performed in triplicates and by calculating mean, standard deviation. The mean of the samples was compared to control using ANOVA.

\section{Result}

\section{Result of preliminary field investigation}

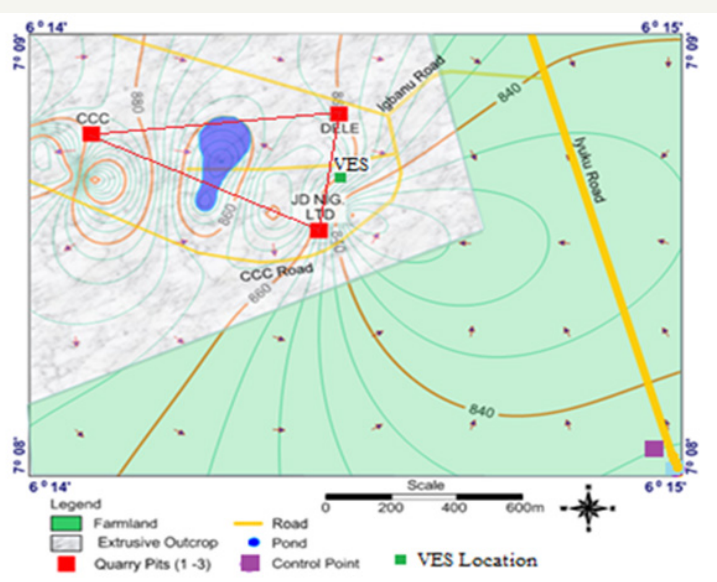

Figure 2: Topographic map of the study area showing direction of drainage.

Figure 2 depicts the topographic map of the study area. It indicates that there is no well-defined direction of drainage (surface runoff) within the study area. This is due to topography and truncated landscape with surface granite rocks often obstructing drainage in the area. The elevation of the study area above mean sea level ranges from $920 \mathrm{ft}$ to $835 \mathrm{ft}$. From photo imagery, the ash colored areas represents the igneous outcrop whereas areas with green color represent farmlands. The farmlands have gentle slope represented by evenly spaced contour lines whereas the areas with the outcrop have steep slope represented by close spaced contour lines. Areas of lower elevation represent the normal ground level (exploited area). The people of the areas are mainly farmers who depend on the clayey weathered top soil, which the farmers confirmed as excellent in crop production.

Preliminary investigations revealed that quarry equipments such as excavators, crusher plants, haulage trucks and the use of explosives during rock blasting generates significant amount of vibrations, noise and dusts that impacts the environment (Figure 3). Different sizes of boulders can be found along-side the massive deposit of the granite (Figure 4). Residents of Iyuku community confirm that these vibrations and noise have destroyed 
some buildings, cause discomfort to the ears of residents, and displacement of biodiversity particularly birds. Findings show different degrees of cracks on the walls of buildings (Figure 5). Community members and quarry workers complained that they sometimes feel a ringing sound in their ears that deprives them of quality sleep. They also reported difficulty in hunting, as most animals particularly antelopes have migrated from the area to more distant areas.

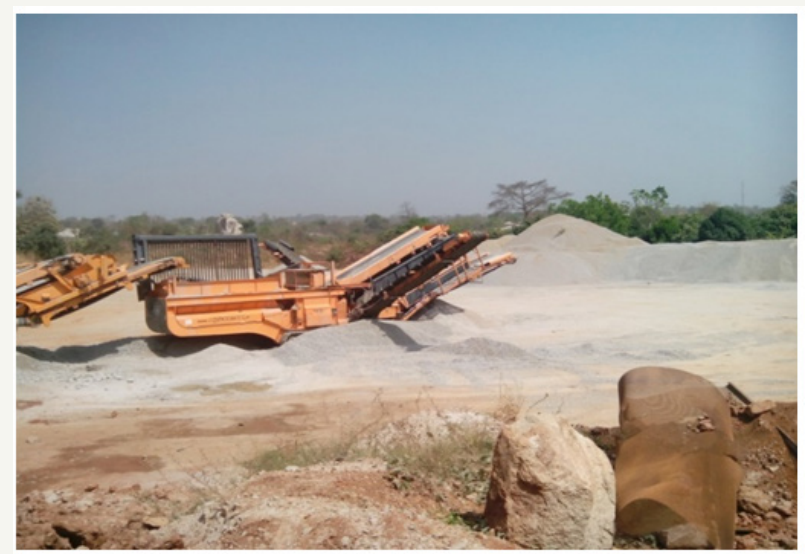

Figure 3: CAT E650 Crusher plant at work in Julius Dinga Quarry.

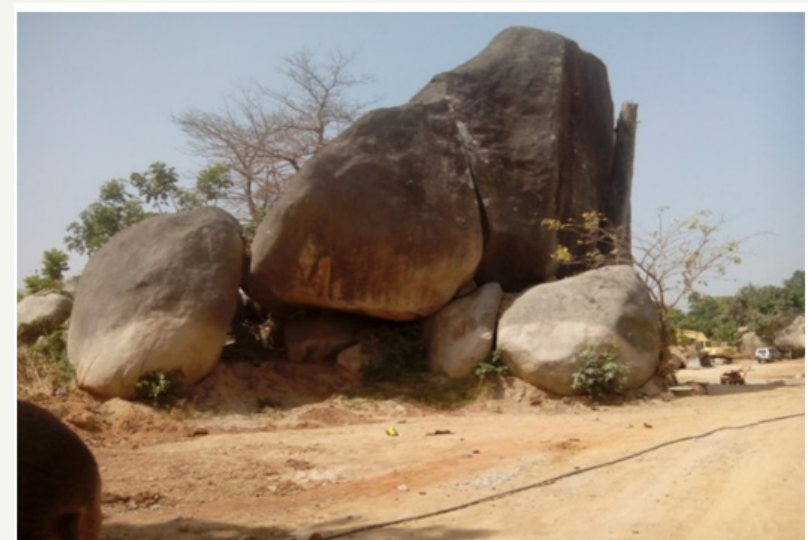

Figure 4: Surface exposed boulder rocks at Iyuku, Auchi, Edo state.
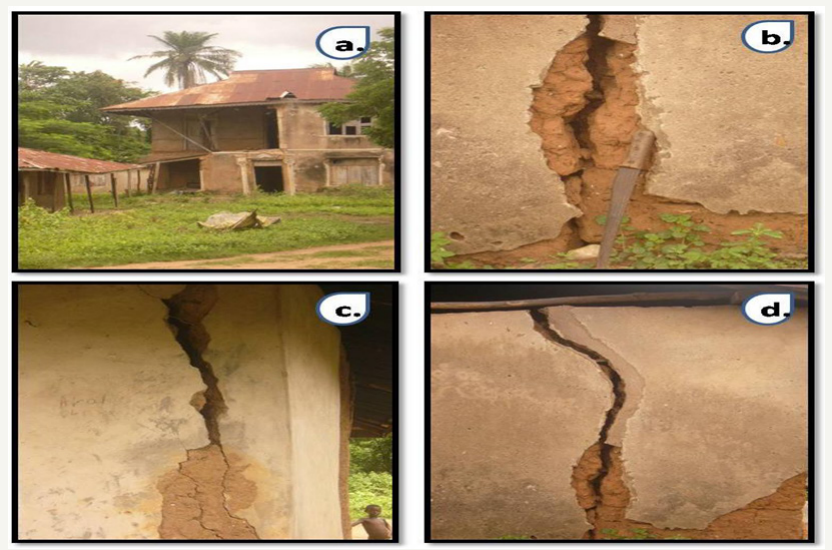

Figure 5(a-d): Indicates different degree of cracks caused by vibrations at igbenu, Iyuku.
An abandoned quarry pit turned pond within the quarry sites (Figure 6) is responsible for the high rate of mosquito and tsetse flies in the area. The abandoned pit turn pond has the characteristics of contaminating groundwater. Investigations show that none of the three active quarries in Iyuku has fully complied with safety rules. Perimeter fences were not constructed in any of the quarries and danger signs were conspicuously absent within the vicinity. Only a few quarry workers at Julius Dinga quarry Ltd were seen wearing ear morphs and nose masks to reduce the effects of noise and dust Figure 3, piles of fine aggregates for asphalting produced by CAT E650 crusher plant at Julius Dinga quarry are continuously exposed to surface environment. Heavy rain falls wash the crushed rock and drain to farm lands and nearby water ways. Figure 5 (a-d) shows the impacts of quarry activities on residential buidings around Iyuku. These visible cracks on buildings threaten community residents. These cracks are produced from the continous use of explosives, quarry equipments, and haulage trucks that traverse the community. Figure 7, shows the Working face of dimension rock quarry in Consolidated Contractors Company (CCC) Quarry Limited, Iyuku. The massive blast with high proportion of bouldersis an indication of excessive use of explosive or uncontrolled blasting, causing geo-hazards.

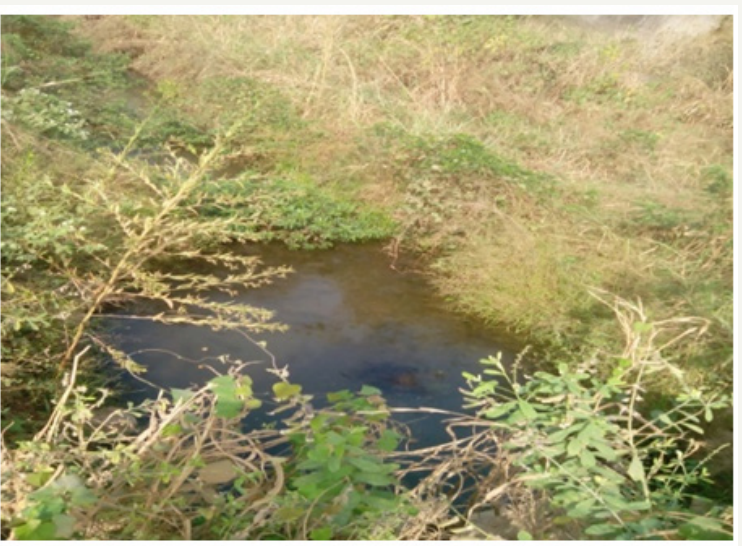

Figure 6: An abandoned quarry pit situated within the sampling sites.

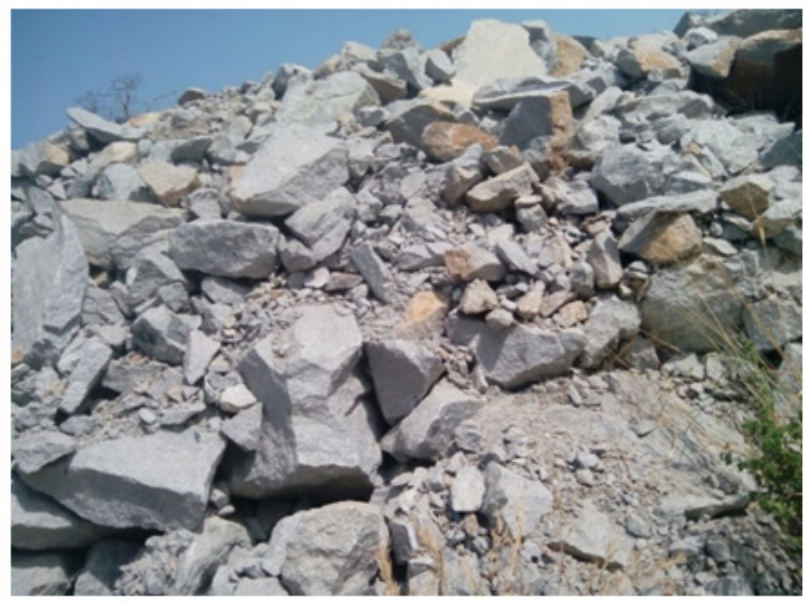

Figure 7: Blasted rocks at consolidated contractor's company. 
Physico-chemical parameters and heavy metals concentration in soil collected from three sampling pits and the control point at different depths (0-15 and 15$30 \mathrm{~cm}$ )

Means with superscript a are significantly different $(\mathrm{P}<0.001)$ from mean of control at different depth respectively using DMR test (Duncan Multiple Range) for pair wise comparison of mean (s) while superscript $\mathrm{b}$ indicates no significant difference $(\mathrm{P} \geq 0.05)$ using DMR test for pairwise comparison of mean $(s) . F(7,23)$ $=1174.21, P=0.204$. Means with superscript a are significantly different $(\mathrm{P}<0.001)$ from mean of control at different depth respectively using DMR test for pair wise comparison of mean (s) while superscript $b$ indicates no significant difference $(P \geq 0.05)$ using DMR test for pair wise comparison of mean $(\mathrm{s})$. F $(7,23)$ $=1174.21, \mathrm{P}=0.204$. MPL=++ Maximum permissible limit (USEPA 1997). NL=No limit.

\section{Result analysis}

\section{Exchangeable cations and anions in soil}

The exchangeable cations analyzed in this study were Calcium, Potassium and Sodium in $\mathrm{mg} / \mathrm{kg}$. These cations, at each pits and depth were significantly different from the control pit $(\mathrm{P}<0.05)$ except potassium at pit 2 which was not different from control at the surface soil $(0-15 \mathrm{~cm}), F(7,23)=1174.21, P=0.204$. See Table 1. The exchangeable cations vary across pits at both surface and subsurface soil. The highest value of calcium was recorded at pit 1 $(192.22 \pm 0.10$ and $189.75 \pm 0.57)$ with the lowest at pit 2 within the surface soil $(64.18 \pm 0.084 \mathrm{mg} / \mathrm{kg})$.

Table 1: Physicochemical parameters of water collected from pond. Numbers in parenthesis are standard (Std) deviations of triplicate determinations. NA: Not Available; FMEnv: Federal Ministry of Environment; WHO: World Health Organization

\begin{tabular}{|c|c|c|c|}
\hline Parameter & Water sample & $\begin{array}{c}\text { FMEnv Std. } \\
\text { (2001) }\end{array}$ & $\begin{array}{c}\text { WHO } \\
\text { Std. }\end{array}$ \\
\hline $\mathrm{pH}$ & $7.52(0.011)$ & $6.5-8.5$ & $6.5-8.5$ \\
\hline Color & $84.10(0.10)$ & NA & NA \\
\hline Conductivity $(\mu \mathrm{s} / \Omega)$ & $30.08(0.072)$ & NA & 1000 \\
\hline Turbidity(NTU) & $2.99(0.0033)$ & $5.0 \mathrm{NTU}$ & $\mathrm{NA}$ \\
\hline $\begin{array}{c}\text { Suspended solid } \\
(\mathrm{mg} / \mathrm{L})\end{array}$ & $6.88(0.12)$ & $<10$ & \\
\hline TDS(mg/l) & $10.63(0.018)$ & 500 & 1000 \\
\hline Calcium(mg/l) & $3.13(0.088)$ & NA & 200 \\
\hline Magnesium(mg/l) & $17.39(0.075)$ & NA & 200 \\
\hline Hardness(mg/l) & $80.33(0.33)$ & NA & NA \\
\hline Alkalinity(mg/l) & $78.10(0.076)$ & NA & NA \\
\hline Chloride(mg/l) & $6.74(0.25)$ & 200 & 250 \\
\hline Phosphate(mg/l) & $0.074(0.0023)$ & $0.01-0.05$ & 0.01 \\
\hline Nitrate(mg/l) & $0.69(0.012)$ & 10 & 10 \\
\hline
\end{tabular}

Potassium was high at surface soil of pit $1(38.31 \pm 0.055)$ while the lowest was recorded at pit $2(9.29 \pm 0.057 \mathrm{mg} / \mathrm{kg})$. For sodium, the highest was also recorded at pit 1 within the surface soil
$(62.9 \pm 0.032 \mathrm{mg} / \mathrm{kg})$ while the lowest was recorded at pit 3 with value far lesser than control at depth of $0-15 \mathrm{~cm}$. See Figure 3a \& $3 \mathrm{~b}$. Among the exchangeable cations, calcium was the highest while the lowest was potassium i.e. $\mathrm{Ca} 2+>\mathrm{Na}+>\mathrm{K}+$ (Table 1 ). Pit 1 was highest in phosphate (P042-) while sulphate (SO42-) was highest in pit 2 compare to other pits and control with concentrations of $24.07 \pm 0.03 \mathrm{mg} / \mathrm{kg}$ and $42.78 \pm 0.31 \mathrm{mg} / \mathrm{kg}$ respectively (Figure $8 \mathrm{a} \&$ $8 b)$.

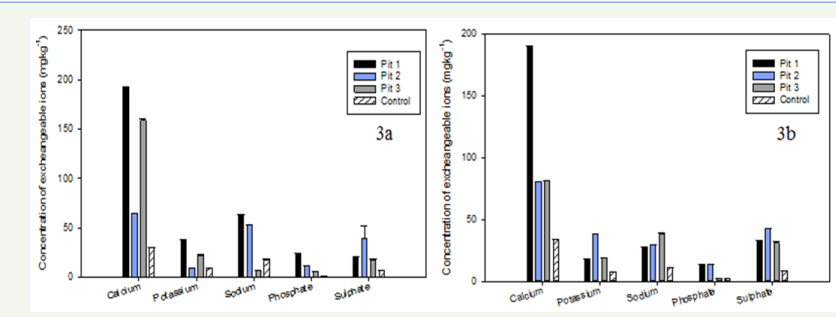

Figure 8: a) concentrations of exchangeable cations and anions in soils of quarry areas and control at depth $0-15 \mathrm{~cm}$. b) Concentrations of exchangeable cations and anions in soils of quarry areas and control at depth $15-30 \mathrm{~cm}$.
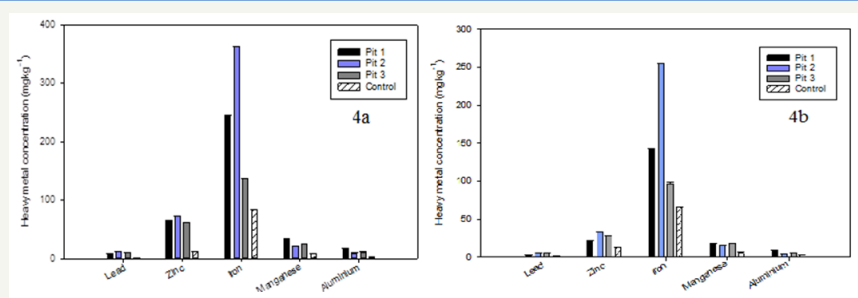

Figure 9: a) Heavy metals concentration in soil samples across quarry areas and control at depth $15-30 \mathrm{~cm}$. b) Heavy metals concentration in soil samples across quarry areas and control at depth $15-30 \mathrm{~cm}$.

\section{Heavy metals concentrations in pits}

Levels of $\mathrm{Fe}, \mathrm{Zn}, \mathrm{Mn}, \mathrm{Al}$, and $\mathrm{Pb}$ in $\mathrm{mg} / \mathrm{kg}$ respectively were 95.97-245.85, 21.28-72.11, 14.85-33.12, 3.91-16.85 and 3.208.69 in all the soil samples from the quarry areas. Also, the levels of $\mathrm{Fe}, \mathrm{Zn}, \mathrm{Mn}, \mathrm{Al}$, and $\mathrm{Pb}$ in $\mathrm{mg} / \mathrm{kg}$ respectively were 65.81-83.85, $12.34-12.39,4.96-8.18,2.89-3.10$ and $0.37-1.24$ in the background (control point). Fe was the highest detected in soils from both quarry areas and background (control). The order of concentration was found as $\mathrm{Fe} 2+>\mathrm{Zn} 2+>\mathrm{Mn} 2+>\mathrm{Al} 3+>\mathrm{Pb} 2+$ (Figure 9a \& 9b).

Pit 2 has the highest concentration of iron at both surface and subsurface soil i.e. $(362.21 \pm 0.017 \mathrm{mg} / \mathrm{kg})$ and $(254.92 \pm 0.16 \mathrm{mg} / \mathrm{kg})$ when compared to control $(83.85 \pm 0.12 \mathrm{mg} / \mathrm{kg})$ and $(65.81 \pm 0.68 \mathrm{mg} /$ $\mathrm{kg}$ ) at each depth respectively. Concentration of Zinc was also highest in pit $2(72.11 \pm 0.015 \mathrm{mg} / \mathrm{kg})$ with the least recorded in control pit at both depths (Figure 9a \& 9b). For manganese and aluminum, the highest was recorded in pit 1 at the surface soil with the least observed in control pit. The highest concentration of lead was recorded in pit 2 at surface soil i.e. $11.74 \pm 0.14 \mathrm{mg} / \mathrm{kg}$ compared to surface soil in control pit $(0.37 \pm 0.019 \mathrm{mg} / \mathrm{kg})$. Hydrogen ion concentration $(\mathrm{pH})$ across all the pits varies with depth, with the highest $\mathrm{pH}$ recorded in pit $3(9.59 \pm 0.095)$ at depth of $15-30 \mathrm{~cm}$ (Figure 10). 


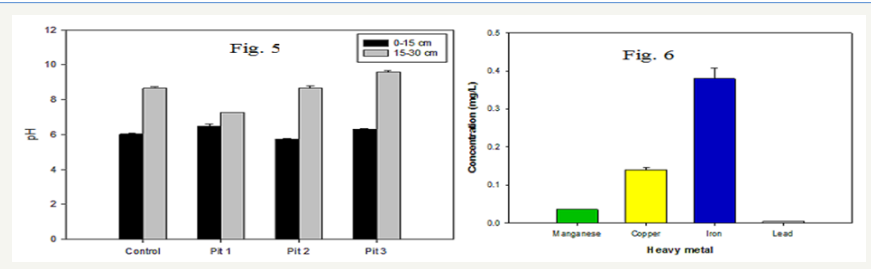

Figure 10: $\mathrm{pH}$ concentration of soil samples across quarry areas and control

Figure 11: Heavy metal concentrations in water collected from pond (abandoned quarry pit) within the quarry.

\section{Physico-chemical and heavy metal content in the pond water}

$\mathrm{pH}$ was within the alkaline range i.e. $7.52 \pm 0.011$. Other parameters such as turbidity, TDS, alkalinities were also within the permissible limits (Table 1). Metal content were as follows: Fe (0.38), Mn (0.035), $\mathrm{Cu}(0.14)$ and $\mathrm{Pb}(0.0033)$. Fe was above the USEPA permissible limit for drinking water while $\mathrm{Pb}$ was very negligible (Figure 11).

\section{Vertical electrical sounding (VES) across the quarry site}

VES revealed twelve geo-electric layers (Figure 12) that was constrained to 5 as follows: Layer one was topsoil with depth $(0.83 \mathrm{~m})$ and resistivity of $115 \mathrm{ohm}-\mathrm{m}$. Layers $2-4$ were silty-sand, and fairly water saturated. Below this overburden was quartzite, followed by the target rock granite of high resistivity $1.6^{5} \Omega-\mathrm{m}$. Presence of quartzite could be described as contact metamorphism of sandstone due to high temperature of ejected volcanic magma. Although, the area has high elevation above mean sea level, groundwater occurs at very shallow depth below topsoil and in pockets of fractures.

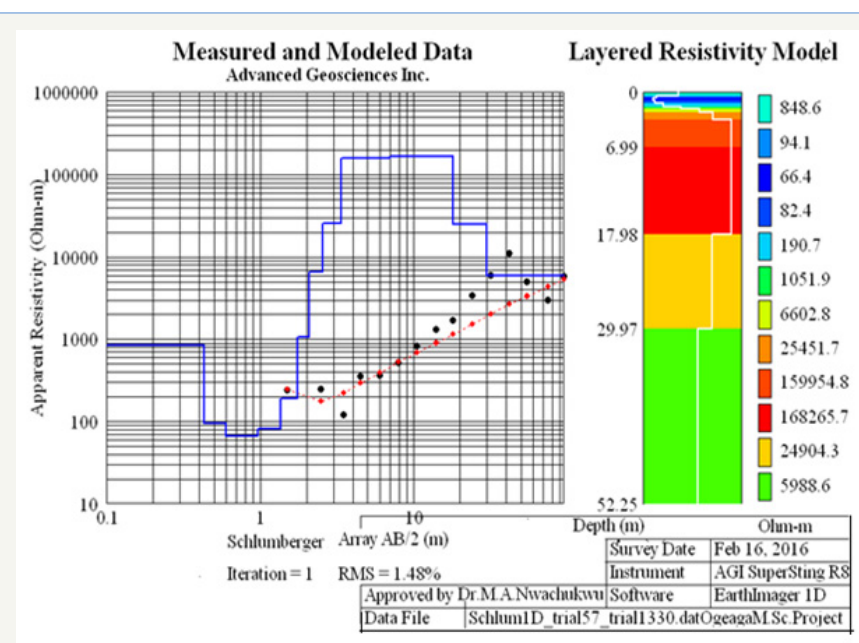

Figure 12: Vertical electrical sounding across the pits within the quarry site.

\section{Result and Discussion}

The results from preliminary field investigations revealed that rock quarrying equipment like haulage trucks, excavators, the use of explosives during blasting operations, crusher plants, and other earth moving equipment used for rock quarrying generates a lot of vibrations, noise and fugitive dust particles that impacts the environment. The vibrations and noise generated have affected buildings, humans and biodiversity in the area. Findings show different degrees of cracks on the wall of residential buildings causing collapse. These cracks are mainly due to seismic waves released by seismic sources (Explosives) during rock blasting. These seismic waves create strong vibrations within the vicinity of the blast. The partially collapsed buildings threaten the lives of humans and livestock that live in them. Collapsed buildings in the area do not only affects humans and biodiversity but result in loss of scarce economic resources.

Due to lack of adequate provision of personal protective equipment (PPE) such as ear morphs', nose masks and safety boots by quarry operators, quarry workers and community members living close to quarry vicinity could sustain fatal injuries; inhale dust particles, and develop hearing loss impairment especially those working in crusher area. The noise has caused the migration of animals such as burrows, birds and antelopes from the quarrying areas to hinter lands. The constant blasting noise and vibration could lead to the extinction of biodiversity [23]. Preliminary findings indicate that uncontrolled quarry in the study area has affected ecosystem due to the destruction of natural landscape and displacement of biodiversity from their habitats. For example, the presence of an abandoned quarry pit not only has a geomorphic effect but also obvious environmental threats to humans and roaming animals. Farmers are scared of the pit and would avoid cultivating close to the pit for the risk of being drowned. This stagnant pond breed vectors like mosquitoes and tsetse flies that cause environmental related deseases, and has the potential to contaminate groundwater.

Concentration of exchangeable cations in the soil across the quarry pits were higher than the background, in order of $\mathrm{Ca}>\mathrm{Na}>\mathrm{K}$. The high concentrations of these cations are due to physical weathering occasioned by blasting and the chemical weathering of feldspar minerals from constituent rocks. The anomalous increase in the concentration of these cations in the quarry area poses significant threats to the environment. These physio-chemical anomalies could result in the deterioration of the soil structure, lowered shear strength and increased compressibility of the topsoil. In effect, the infiltration capacity and water availability of the soil will reduce, thereby supporting the accumulation of rain water on the soil surface and flooding in the area. Severe flooding could cause gully erosion; destruction of farmlands, render residents homeless, drowning of people and displacement of burrow animals from their natural habitat.

Potassium, a major constituent of felsic igneous rocks could progressively accumulate in the soil through the weathering of feldspar minerals. Levels of potassium (18.61- $40.0 \mathrm{mg} / \mathrm{kg}$ ) in soil within quarry areas and 7.22-8.61 in the background confirms anomalous concentration within and around the quarry site. Very high levels of $\mathrm{K}+$ in soil could cause damage to plants by inhibiting the uptake of other minerals and reducing crop production. When crop production reduces, economy of the residents who 
are predominantly farmers is affected. This situation could cause serious aggression among the poor farmers that often manifest into conflict with the quarry operators. Heavy metals analysis confirmed anomalous concentration of Iron (Fe), Zinc (Zn), Manganese (Mn), Aluminum ( $\mathrm{Al})$ and Lead $(\mathrm{Pb})$ compared with the background values indicating soil degradation due to quarry activities in Iyuku. Seepage and infiltrate of these heavy metals to the near-surface water table could cause serious pollution of groundwater in Iyuku. Their final residence in groundwater could cause long term health risk to humans. Zinc toxicity will inhibit $\mathrm{CO} 2$ fixation, and alter membrane permeability, thus rendering land unsuitable for plant growth in the quarry area [24].

The $\mathrm{pH}$ concentrations show that surface soils $(0-15 \mathrm{~cm})$ across the quarry area is acidic which supports the precipitation and mobilization of heavy metals. Such acidic soils can reduce the ability of microbes to fix atmospheric nitrogen and retarding the breakdown of organic matter, thus rendering such land unsuitable for plant growth. $\mathrm{pH}$ of the pond read 7.2, which imply that the pond is slightly alkaline and maybe favorable to the existence of bacteria. The excess phosphate is a source of nutrients to plants and it's responsible for the heavy growth of plants on the water surface. Figure 6 shows the concentration of heavy metals in the abandoned pond. Iron concentration in the pond far exceeds allowable limits. The high concentration of Iron ( $\mathrm{Fe}$ ) in the water enhances the growth of iron dependent bacteria that affects the water taste, cause production of slimes and objectionable odor. VES investigation indicate occurrence of water at relatively shallow depths, in pockets of rock fractures confirming that heavy metals and toxins could easily infiltrate or leach through the soil profile to contaminate groundwater in Iyuku.

\section{Affordable safety measures}

To improve environmental safety within the quarry sites, there should be perimeter fence and safety warning signs round quarry pits. This will restrict movements, reduce accidents and enhance safety of both humans and roaming animals [26-28]. Quarry operators should provide personal protective equipment and ensure that workers always put on protective head helmets, safety boots. This will help reduce cases of injury or death that may arise due to frequent rock fall. Blasting of rocks should be regulated and monitored; regulating the times of blasting, maintaining appropriate distance between blasting face and any sensitive property, keeping explosive charge per hole as low as possible, and applying delay elements per hole detonation. Haulage trucks must cover their loaded materials with thick tarpaulin, to avoid hazards arising from flying rocks [29-30].

\section{Conclusion}

Rock quarry has brought both positives and negatives values in Iyuku. The positive values include job opportunity, and revenue generation to state and the community. The negative values include air, soil, and noise pollution, encroachment into agricultural land, cracks on buildings and structural failures. Others are breeding of mosquitoes, gradual loss of biodiversity, possible contamination of groundwater, and creation of dangerous landscape. We therefore conclude that quarry activities in Iyuku account for total environmental degradation that can be described as unsustainable mining practice.

\section{Recommendations}

The under listed initiatives are projected to account for a sustainable quarry practice in Iyuku:

i. Proper site evaluation prior to quarry development conducted by accredited professionals

ii. Proper review and stringent enforcement of quarry operational guidelines and regulations by government agency; Incorporate site reclamation in the lease agreement.

iii. Import duty rebates to quarry operators importing environmentally friendly technology

iv. Quarry operators to pay environmental taxes or have tax exemptions for application of environmentally friendly technology

v. Proper design of quarry pits; benching and haulage roads

vi. Application of control blasting to minimize vibration

vii. Provision of affordable safety measures such as perimeter fencing and warning signs

viii. Quarry operators to reclaim site or provide reclamation fund before leaving a site. To reduce cases of abandoned pits and formation of ponds

ix. Need for periodic environmental auditing and monitoring of quarry sites

x. Host community to be part of the quarry lease and operation; from pit opening to final closing, ensuring reclamation

\section{Acknowledgement}

Authors are grateful to GEOPROBE Int'l Consult LTD Owerri for supporting this study through provision of field instrumentation and logistics. We are also grateful to the toxicology laboratory of the University of Benin for making the analytical instruments available.

\section{References}

1. Rahaman MA (1989) Review of Basement Geology of Southwestern Nigeria. In: Kogbe CA (Ed.), Geology of Nigeria. ( $\left.2^{\text {nd }} e d n\right)$, pp. 49-63.

2. Keeperman SO (2000) Distribution and forms of copper, zinc, cadmium, iron and manganese in soils near a copper smelter. Journal Soil Science 135(2): 101-109

3. Bayramin I, Basaran M, Erul G, Canga RM (2008) Assessing the effect of land use changes on soil sensitivity to erosion in Turkey. Environ Mon and Asses 140(1-3): 249-265.

4. Maponga O, Munyanduri N (2001) Sustainability of the dimension stone industry in Zimbabwe-challenges and opportunities. Natural Resources Forum 25(3): 203-213.

5. Nwachukwu MA (2002) Seismic Techniques in the control of effects due 
to blasting vibration during construction of Jebba dam, Nigeria, Journal of Environ Analar 8: 1014-1035.

6. Stehouwer R, Day R, Macneal E (2006) Nutrient and trace element leaching following mine reclamation with biosolids. Journal of Environ Quality 35(4): 1118-1126.

7. Lad RJ, Samant JS (2014) Environmental and social impacts of stone quarrying-a case study of Kolhapur District. International Journal of Current Research 6(3): 5664-5669.

8. Nwachukwu MA, Nwachukwu MI, Ahiarakwem CO, Nwankwo GI (2017) Abandoned Borrow Pits; Risk Factors and Reclamation Procedure. MO] Civil Eng 2(3): 00033.

9. Anand PB (2006) Waste management in madras revisited. Environment and urbanization. 11(2): 161-176.

10. Mabogunje AL (2008) The Debt to posterity: Reflection on a national policy on environ Mgt. In: Sada NPO, Odemerho T (eds.), Environ Issues and Mgt in Nigerian 750: 6669.

11. Onyedika GO, Nwosu GU (2008) Lead, zinc and cadmium in root crops of mineralized galena-sphalerite mining areas, and environ. Pakistan Jl of Nut 7(3): 418-420.

12. Oluyemi EA, Feuyit G, Onekunle JAO, Ogunfowokan AO (2008) Seasonal variation in heavy metal concentration in soil and some selected crops at a landfill in Nigeria. African Journal of Environmental Science and Technology 2(5): 89-96.

13. Ashraf MA, Maah MJ, Yusoff L (2011) Heavy metals accumulation in plants growing in ex tin mining catchment. Int J Environ Sci Techn 8(2): 401-416.

14. Ezeaku PI (2012) Eval the influence of open cast mining on soil, land and livelihood in areas of Nasarawa, North-Central Nigeria. J Ecol and the Natural Environ 4(3): 62-70.

15. Nnabo PN (2015) Assessment of heavy metal contamination of water sources from Enyigba Pb-Zn District, SE Nigeria. Int'l Jl of Scientific and Techn Res 4(9): 187-197.

16. Idris GN, Asuen GO, Ogundele OJ (2014) Environ Impact on Surface and G'dwater from Mining Activities in Ikpeshi, Edo State, Nigeria. Int'l Jl of Geosc 5(7): 749-755.

17. Ukpong EC (2012) Environ impact of aggregate mining by crush rock industries in Akamkpa Cross River State. Nigerian Jl of Techn 31(2): 128-138.
18. Igwe O, Adepehin EI Iwuanyanwu C (2012) Environ effects of Pb-Zn minig in Enyigba and its suburbs, S. Benue Trough. Nig Jl of Educ Heath and Techn Res 3(2): 30-44

19. Lad RJ, Samant JS (2015) Impact of bauxite mining on soil: a case study of bauxite mines at Udgiri, Dist-Kolhapur, India. Int'l Res Jl of Environ Sci 4(2): 77-83.

20. Tsuwang KD, Ajigo IO, Lar UA (2014) Assessment of lead, mercury and arsenic in soils of Anka area, NW Nigeria. Int'l Jl of Sci Environ and Techn 3(1): 187-197.

21. Okafor FC (2006) Rural Development and the Environ Degradation versus Protection: In Sada PO, Odemerho T (eds.), Environ Issues and Mgt in Nig Devpt pp. 150-163.

22. Aremu MO, Atolaiye BO, Labaran L (2010) Environ implication of metal in soil, plant and foods Udege in Mines of Nigeria. Ethiopian Bull of Chem Society 24(3): 351-360.

23. Lamid EA, Ayodele GA (2010) Effects of quarry activities on biodiversity in: Case study of Ogbere site, Nig. African Jl. of Environ Sc Tech 4(11): 740-750.

24. Tilmub BM, Sarkodic PA, Monney I, Maxwell PO (2015) Heavy metal contam of soil by quarry dust Ashanti Ghana. Jl of Chem and Mat Res $7(5): 42-50$.

25. Nwachukwu MA, Huan F (2012) Environmental hazards and sustainable development of rock quarries lower Benue trough, Nigeria. Int'l Jl of Sustainable Devpt 5(6): 8.

26. Antunes IMHR, Neiva AMR, Silva MMVG (2008) Environ contamination of abandoned mines at Central Portugal. Mine Water and the Environ Proc, pp. 351-354

27. Federal Ministry of Environment (FME) (2001) National Guidelines and Standards for Water Quality in Nigeria, Federal Ministry of Environment, Nigeria. p. 1050.

28. Gunduz 0, Simsek C (2008) Mechanisms of as contamination of a surfacial aquifer in Turkey. Proc $6^{\text {th }}$ Int'l Groundwater Qual Conf Fremantle, Australia. pp. 1-8.

29. Johnston D, Potter H, Jones C, Rolley C, Watson I et al. (2008) Abandoned mines and the water environ. SPR SC030136-41. Environment Agency, Bristol, UK, p. 31.

30. United States Environmental Protection Agency (USEPA) (2002) Current Drinking Water Standards, p. 467.

\section{Your subsequent submission with Crimson Publishers will attain the below benefits}

Creative Commons Attribution 4.0

International License

For possible submissions Click Here

Submit Article 